\title{
Idiopathic Subglottic Stenosis
}

\author{
Christine M Carmichael* \\ Woolfolk School of Communication Sciences and Disorders, Our Lady of the Lake University, USA
}

*Corresponding author: Christine M Carmichael, Our Lady of the Lake University, 411 SW 24th St, San Antonio, Texas 78207, USA.

Received Date: May 31, 2021

Published Date: July 16, 2021

\begin{abstract}
The treatment of idiopathic subglottic stenosis is a challenge. There is no consensus regarding efficacious treatments that prevent restenosis and granulation formation. Commonly used in-office and surgical procedures are reviewed. Patient compliance and follow-up is imperative in the quest to prevent recurrence.
\end{abstract}

Keywords: Idiopathic; Subglottic; Stenosis; Surgery; Treatment

Abbreviations: ISGS: Idiopathic subglottic stenosis; COPD: Chronic obstructive pulmonary disease; $\mathrm{CO}_{2}$ : Carbon dioxide; PFTs: Pulmonary function tests; PVFM: Paradoxical vocal fold motion

\section{Introduction}

Subglottic stenosis involves an obstruction comprised of scar tissue in the proximal trachea below the glottis which significantly narrows the airway near the first 2 tracheal rings [1,2]. The most common etiology is iatrogenic from prolonged intubation and tracheotomy [3], recently compounded by those who needed those interventions due to COVID-19 [4]. Subglottic stenosis may also develop in auto-immune diseases, namely granulomatosis with polyangiitis [5]. Idiopathic subglottic stenosis (iSGS) is the rarest type that primarily affects Caucasian (97\%), perimenopausal (average age 50 years) females (98\%) [5,6]. Female predominance has lead researchers to believe hormone receptors are involved in the disease process. In fact, specimens from females with iSGS have elevated levels of estrogen-alpha and progesterone receptors but no expression of estrogen-beta which normally plays a role in wound healing $[7,8]$. In addition, co-morbidities of high body mass index, laryngopharyngeal reflux and diabetes have been associated with iSGS $[9,10]$. Other research has identified mycobacterium tuberculosis complex pathogens in iSGS [11], suggesting that airway bacteria may play a role in the keloid tissue overgrowth.
ISGS is diagnosed when pulmonary involvement has been ruled out through imaging, and testing for auto-immune conditions are negative.

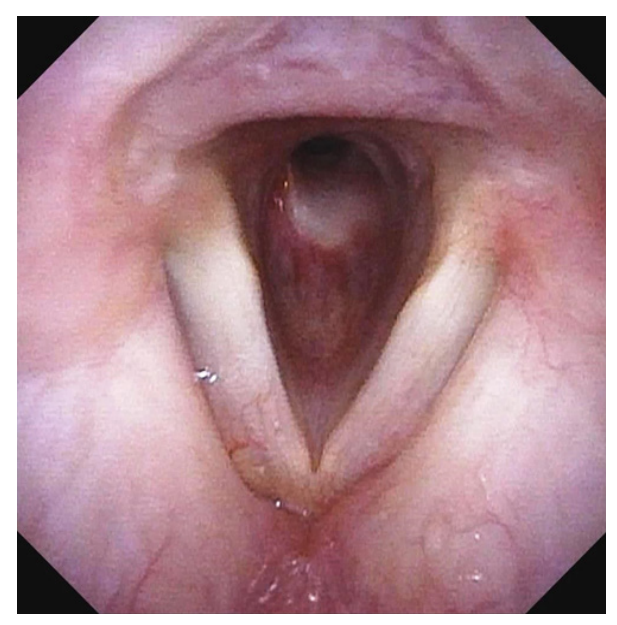

Figure 1: Subglottic stenosis reducing the lumen by approximately $90 \%$. 
Symptoms of iSGS include dyspnea, wheezing, stridor, cough, exercise intolerance and airway obstruction [3,12]. Findings of airway obstruction often lead to misdiagnosis of asthma or COPD with an average duration before proper diagnosis of 2.8 years [13]. Patients seek medical attention when the stenosis becomes severe enough to impact their daily activities when more than $50 \%$ of the airway is blocked (see example Figure 1). Endoscopic evaluation is an essential part of iSGS diagnosis. The Myer-Cotton system [14] is widely used to classify the grade of obstruction with most reaching a grade III (71-99\% blockage) before surgical intervention.

Although there are several schools of thought for optimal treatment strategies, none seem to successfully prevent recurrence. Multimodality approaches offer the best outcome: CO2 laser radial incisions with gentle balloon dilation are commonly used [15] along with intralesional injections of steroids. Corticosteroids act to decrease scar formation and can also be injected into scar tissue in the office under laryngoscopy in an attempt to prolong the duration between surgical procedures. Anti-reflux therapy may aid in reducing recurrence. Stents may be used if structural integrity of the trachea is compromised. Understandably, severe obstruction and respiratory failure may warrant tracheostomy. Tracheostomy with Montgomery T-tube placement is a permanent option for high risk surgical candidates [16]. Other surgical techniques include laryngotracheal reconstruction and an experimental "Maddern procedure" that shaves off the stenosis endoscopically and relines the cricoid with a graft held in place for a couple of weeks with a silicone stent [17].

\section{Discussion}

Idiopathic subglottic stenosis is a rare disorder of unclear etiology and pathogenesis. Although first described almost 50 years ago [18], diagnosis and management remains challenging. The primary aims of medical management for iSGS are symptomatic improvement of breathing with airway patency while preserving the voice and swallow. In-office endoscopic and surgical procedures make up the bulk of treatments utilized but experimental techniques and anti-bacterial medications may play a role against recurrence and render the need for more investigation.

\section{Acknowledgement}

No acknowledgement.

\section{Conflict of Interest}

No financial interest or conflict of interest exists.

\section{References}

1. Valdez TA, Shapshay SM (2002) Idiopathic subglottic stenosis revisited. Ann Otol Rhinol Laryngol 111: 690-695.
2. McCaffrey TV (1992) Classification of laryngotracheal stenosis. Laryngoscope 102: 1335-1340.

3. Gelbard A, Francis DO, Sandulache VC, Simmons JC, Donovan DT, et al. (2015) Causes and consequences of adult laryngotracheal stenosis. Laryngoscope 125(5): 1137-1143.

4. Anderson C, Sandhu G, Al Yaghchi C (2021) Impact of the COVID-19 pandemic on patients with idiopathic subglottic stenosis. Ear Nose Throat J 100 (25): 122S-130S.

5. Gadkaree SK, Pandian V, Best S, Motz KM, Allen C, et al (2017) Laryngotracheal stenosis: risk factors for tracheotomy dependence and dilation interval. Otolaryngol Head Neck Surg 156(2): 321-328.

6. Lee J, Huang L, Berry LD, Anderson C, Amin MR, et al. (2021) Association of Social Determinants of Health with Time to Diagnosis and Treatment Outcomes in Idiopathic Subglottic Stenosis. Ann Otol Rhinol Laryngol.

7. Fiz I, Bittar Z, Piazza C, Koelmel JC, Gatoo F, et al. (2018) Hormone receptors analysis in idiopathic progressive subglottic stenosis. Laryngoscope 128(2): E72-E77.

8. Damrose EJ, Campbell RD, Darwish S, Erickson-DiRenzo E (2020) Increased expression of estrogen receptor beta in idiopathic progressive subglottic stenosis. Laryngoscope 130(9): 2186-2191.

9. Scholfield DW, Warner E, Ahmed J, Ghufoor K (2021) Subglottic and tracheal stenosis associated with coronavirus disease 2019. J Laryngol Otol 11: 1-3.

10. Nicolli EA, Carey RM, Farquhar D, Haft S, Alfonso KP, et al. (2017) Risk factors for adult acquired subglottic stenosis. J Laryngol Otol 131(3): 264-267.

11. Gelbard A, Kataantonia N-G, Mizata M, Newcomb D, Rotsinger J, et al. (2016) Molecular analysis of idiopathic subglottic stenosis for Mycobacterium species. Laryngoscope 127: 179-185.

12. Menapace DC, Ekborn DC, Larson DP, Lalich IJ, Edel ES, et al. (2019) Evaluating the association of clinical factors with symptomatic recurrence of idiopathic subglottic stenosis. JAMA Otolaryngol Head Neck Surg 145(6): 524-529.

13. Perotin J-MM, Jeanfaivre T, Thibout Y, Jouneau, S, Lena H, et al. (2011) Endoscopic management of idiopathic tracheal stenosis. Ann Thorac Surg 92: 297-301.

14. Myer CM, O'Connor DM, Cotton RT (1994) Proposed grading system for subglottic stenosis based on endotracheal tube sizes. Ann Otol Rhinol Laryngol 103: 319-323.

15. Tremblay A, Coulter TD, Mehta AC (2003) Modification of a mucosal-sparing technique using electrocautery and balloon dilation in the endoscopic management of web-like benign airway stenosis. J Bronchol 10: $268-271$.

16. Jin B, Wang T, Wang Y, Zhang J (2021) Montgomery T-tube insertion under ECMO ina apatient with complete subglottic stenosis and severe lower tracheal collapse. Ear Nose Throat J.

17. Aravena C, Almeida FA, Mukhopadhyay S, Ghosh S, Lorenz RR et al. (2020) Idiopathic subglottic stenosis: a review. J Thorac Dis 12(3): $1100-1111$.

18. Brandenberg JH (1972) Idiopathic subglottic stenosis. Trans Am Acad Opthalmol Otolaryngol 76: 1402-1406. 